\title{
Development of a vaccine to prevent Japanese encephalitis: a brief review
}

This article was published in the following Dove Press journal:

International Journal of General Medicine

14 October 2009

Number of times this article has been viewed

\section{Viroj Wiwanitkit}

Wiwanitkit House, Bangkhae, Bangkok, Thailand
Correspondence: Viroj Wiwanitkit Wiwanitkit House, Bangkhae, Bangkok 10160, Thailand

Tel +6624I32436

Email wviroj@yahoo.com
Abstract: Japanese encephalitis (ICD 10: A83.0) is an important specific viral encephalitis caused by the Japanese encephalitis virus, a virus of the Flavivirus group. Millions of people, especially those in endemic areas of developing countries in Asia, are at high risk from this infection. Therefore proper management to deal with this virus is essential. There is no specific treatment for Japanese encephalitis virus. Supportive and symptomatic treatments are usually used, which emphasize the importance of prevention in this specific neurological disorder. Vector control or vaccination can be used to prevent the disease. Because the existing Japanese encephalitis vaccine poses some undesirable problems, a new vaccine is needed. The process of developing a new vaccine is briefly discussed.

Keywords: Japanese encephalitis, vaccine, concept, prevention, development

\section{Introduction to Japanese encephalitis ${ }^{1-4}$}

Acute inflammation of the brain is the hallmark of encephalitis. Encephalitis has several causes, including biological, chemical and physical insults. Infection is an interesting cause of encephalitis. Several infections can lead to encephalitis, among which viral infections are important. ${ }^{5,6}$ Viral encephalitis can be fatal, and usually presents problems for the physician. ${ }^{5,6}$ Many viruses causing encephalitis are documented in the medical literature, among which Japanese encephalitis (ICD 10: A83.0) is important. Japanese encephalitis is a specific neurological disturbance that is caused by Japanese encephalitis virus, which is a member of in the Flavivirus group. ${ }^{7}$

Japanese encephalitis is classified as an important mosquito-borne infection. ${ }^{8-12}$ Mosquito vectors are Culex spp, especially $C$. gelidus and C. tritaeniorhynchus. ${ }^{13-15}$ These vectors usually live in fields and water reservoirs in rural and suburban areas. $^{8-12}$ The disease can be frequently seen in developing countries in Asia, where suitable breeding sites of the mosquito vectors are abundant. Because of the nature of this vector-borne disease, it remains a focus of public health around the world, especially in tropical regions (Table 1). Because millions of people, especially those in developing countries, are at high risk from this viral infection, proper management of this disease is essential.

Another interesting feature of the transmission cycle of Japanese encephalitis virus is that pigs can harbor the virus and act as an amplifying host. ${ }^{27-31}$ Because the virus can then be further transmitted by mosquitoes to humans, it can be classified as a pig-related disease. The disease is common in many pig-farming areas. A case presenting classical viral encephalitis symptoms with a history of living in a 
Table I Situation of Japanese encephalitis in different regions of the world

\begin{tabular}{|c|c|}
\hline Areas & Details \\
\hline Asia ${ }^{16-19}$ & $\begin{array}{l}\text { Tropical Asia is the endemic area of Japanese encephalitis. There are many outbreaks in Asia in each year. South Asia (especially India) } \\
\text { and Southeast Asia are the two main regions where Japanese encephalitis is prevalent. Poverty is a big underlying risk factor for } \\
\text { Japanese encephalitis in Asia. However, this does not mean that there is no problem for rich countries. Of interest, Japan, from where } \\
\text { the name Japanese encephalitis is derived, still has this disease although it is controlled. }{ }^{19}\end{array}$ \\
\hline Africa & $\begin{array}{l}\text { Although the socioeconomic status is lower than in Asia, the prevalence of disease is nil, because of the geographical pattern } \\
\text { of Japanese encephalitis. However, there is confirmed evidence for an intermediate risk of Japanese encephalitis transmission } \\
\text { in Africa (compared to high risk for dengue). }{ }^{20}\end{array}$ \\
\hline Australia & Japanese encephalitis is a new emerging arbovirus infection in Australia. ${ }^{21-26}$ \\
\hline South America & The Americas are currently not at risk of Japanese encephalitis. \\
\hline
\end{tabular}

pig-farming area or having traveled to or through such an area should raise strong suspicions of infection with Japanese encephalitis. ${ }^{31}$ During disease surveillance, patients should be asked about their history of contact with pigs (pig farming, slaughtering, butchering and transport, and living in a pig-farming area). However, because other hosts, including other mammals and birds, notably water fowl, can amplify the disease, these should also be taken into account during disease surveillance and control. It should be noted that only 1 in 1000 patients who contract the virus from a mosquito bite develop a full-blown illness. However, the mortality from full-blown disease is very high (up to $10 \%$ to $20 \%$ ), and two-thirds of the survivors suffer permanent neurological defects.

The incubation period after infection from a mosquito bite is usually 2 to 4 days. The common, but not specific, presentation is fever, either high or low. Some cases can also present flu-like symptoms. Most recover from the illness without treatment, but sometimes encephalitis develops. Neurological manifestations are usually the starting point for clinical diagnosis. Indeed, in tropical endemic areas, any patient presenting with fever and the neurological signs and symptoms should receive a complete assessment for possible viral encephalitis. Briefly, the common symptoms include alteration of consciousness and seizure. An alteration in EEG is also detectable. Encephalitis is the presumptive diagnosis for such cases. However, because the neurological manifestations of Japanese encephalitis are highly similar to those of other kinds of viral encephalitis, simple clinical observation does not easily differentiate between Japanese encephalitis and the other kinds of encephalitis. A laboratory investigation is invariably necessary.

As already mentioned, diagnosing Japanese encephalitis is not easy. The clinical diagnosis requires further verification by standard medical laboratory investigation. Immunodiagnosis, the basic diagnostic laboratory test, remains the gold standard. However, confirmed diagnosis is usually late in the course of the disease because the patient will usually have full-blown neurological signs and symptoms before the physician in charge becomes aware of the possibility of a diagnosis of Japanese encephalitis. ${ }^{1-4} \mathrm{~A}$ few commercial

Table 2 Neurological manifestations of Japanese encephalitis ${ }^{1-4,32-35}$

\begin{tabular}{|c|c|}
\hline Aspects & Descriptions \\
\hline Signs and symptoms & $\begin{array}{l}\text { Fever (high or low), nausea and vomiting, stupor, alteration of consciousness, loss of consciousness, seizure (generalized or } \\
\text { focal). }\end{array}$ \\
\hline Laboratory findings & $\begin{array}{l}\text { Cerebrospinal fluid (CSF) profile shows white blood cells about } 5-500 / \mathrm{mm}^{3} \text { with lymphocyte predominance (however, } \\
\text { neutrophilia can be seen in the first } 3 \text { days). CSF protein is about } 50-200 \mathrm{mg} / \mathrm{dL} \text { and CSF sugar is not depleted. It should be } \\
\text { noted that this is not specific for Japanese encephalitis but a common CSF profile for all viral encephalitis. }\end{array}$ \\
\hline Definite diagnosis & $\begin{array}{l}\text { Definite diagnosis is based on immunodiagnosis. }{ }^{\mid-4} \text { Specific Japanese encephalitis IgM (by ELISA) in CSF or serum } \geq 40 \text { units } \\
\text { (in serum, the ratio of Japanese encephalitis/dengue IgM by ELISA must be more than I). In case of death, definite diagnosis } \\
\text { can also be made during autopsy. The main finding is the detection of Japanese encephalitis antigen in the brain tissue. }{ }^{35}\end{array}$ \\
\hline EEG & $\begin{array}{l}\text { Alteration of EEG pattern can be seen corresponding to the presentation of seizure. According to Misra and Kalita, "Upon } \\
\text { comparison of the JE patients with and without seizures, EEG slowing and cortical and thalamic lesion on CT or MRI were } \\
\text { significantly related to the occurrence of the seizures; however, it was not associated with poor outcome." } 32\end{array}$ \\
\hline Imaging & $\begin{array}{l}\text { There is no specific significant finding on } \mathrm{CT} \text { or MRI. }{ }^{33} \text { However, as noted by Misra and Kalita, the specific lesion that might } \\
\text { be related to the seizure, but not the prognosis, should be kept in mind. } .^{32,34}\end{array}$ \\
\hline
\end{tabular}


Table 3 Details of classical inactivated mouse brain Japanese encephalitis vaccine ${ }^{36-38}$

\begin{tabular}{|c|c|}
\hline Aspects & Descriptions \\
\hline Type & $\begin{array}{l}\text { This is an inactivated vaccine, derived from controlled infected mouse brain. The inactivation of the virus from infected } \\
\text { mouse brain is due to formalin application. }{ }^{40,41} \text { After inactivation, the vaccine is further purified. Two main strains are used } \\
\text { for production of Japanese encephalitis vaccine: Nakayama and Beijing (the latter strain is the better) }\end{array}$ \\
\hline Composition & $\begin{array}{l}\text { I } \mathrm{mL} \text { of vaccine consists of } 80 \mathrm{I} \mu \mathrm{L} \text { of effective protein ( } 97 \% \text { is the antigenic protein of Japanese encephalitis virus), } \\
\text { thimerosol (as preservation) and gelatin (as stabilizer) }\end{array}$ \\
\hline Package & $\begin{array}{l}\text { There are two package forms of Japanese encephalitis vaccine including liquid and lyophilized forms: liquid form as either } \\
\text { I mL/dose (for Nakayama strain) or } 0.5 \mathrm{~mL} / \text { dose (for Beijing strain); lyophilized (freeze-dried form) as } 0.5 \mathrm{~mL} / \text { dose } \\
\text { (for Beijing strain). The lyophilized form has a longer shelf life }\end{array}$ \\
\hline Administration & $\begin{array}{l}\text { Subcutaneous injection is recommended. For general cases, I dose must be injected at the deltoid area. For children aged } \\
\text { less than } 3 \text { years old, half dosage is recommended for injection at the thigh area }\end{array}$ \\
\hline Schedule & $\begin{array}{l}\text { According to the general expanded program for immunization (EPI), vaccination is suggested for children in endemic areas } \\
\text { starting at } 12 \text { months. The vaccination schedule is on day } 0, I \text { month and I year. For highly endemic areas, a fourth booster } \\
\text { dosage is recommended at } 5 \text { years. For visitors to endemic areas, pre-exposure vaccination is recommended, at day } 0 \text {, day } 7 \\
\text { and I month. A special extra short schedule at day } 0 \text {, day } 7 \text { and day } 14 \text { is also acceptable (but offers less protection) }\end{array}$ \\
\hline Contraindication $^{36-38}$ & $\begin{array}{l}\text { The main contraindications include fever and pregnancy. The relative contraindications are severe heart disease, severe liver } \\
\text { disease, severe kidney disease and those with history of vaccine allergy or seizure within previous year }\end{array}$ \\
\hline Adverse effect ${ }^{36-38}$ & $\begin{array}{l}\text { Localized inflammation at injection site can be seen at a rate of about } 10 \%-20 \% \text { and is most common at first dose. } \\
\text { Sometimes, fever can be seen owing to the inflammation. Angioedema can also be seen at day I to day } 3 \text {, at about } \\
0.2 \%-0.6 \% \text {, and is commonly detected at the second dose. Rarely, neurological complications such as encephalopathy } \\
\text { can also be detected. Anaphylaxis due to vaccination is rare }\end{array}$ \\
\hline Storage & $\begin{array}{l}\text { The vaccine has to be refrigerated at } 2-8^{\circ} \mathrm{C} \text {. The diluted lyophilized vaccine can be kept for I day. The shelf life for liquid } \\
\text { vaccine is I year and the shelf life of lyophilized vaccine is about } 3-5 \text { years }\end{array}$ \\
\hline
\end{tabular}

kits for detecting Japanese encephalitis are available. In addition, as a vector-borne disease of poor, developing countries, pharmaceutical companies in the developed world have little interest in the disease.

As member of the Flavivirus group, there is no specific treatment. ${ }^{1-4}$ All cases need supportive and symptomatic treatment in hospital, which emphasizes the importance of prevention. Intravenous fluid (usually 5\% dextrose half strength saline solution) administration at maintenance dose is recommended. Seizures can be treated with an anticonvulsive drug such as phenytoin and phenobarbital.

\section{Vaccination ${ }^{36-38}$}

Prevention can be by either vector control or vaccination. Mosquito control is difficult because of their sheer numbers. Preventing mosquito bites will be more effective than mosquito control, but this is also sometimes very difficult. Vaccination seems to be the most effective alternative preventive. Japanese encephalitis vaccine is available and used in many countries. In clinical practice, the inactivated mouse brain Japanese encephalitis vaccine (BIKEN/JEVAX vaccine) is widely used. Other vaccines are also used in some parts of the world, including the dead Nakayama strain vaccine used in parts of China and the live SA14-14-2 vaccine used in China and some Asian countries, including Thailand. ${ }^{38,39}$

A three-dosage vaccination schedule is recommended to achieve full immunity in endemic areas in which the virus is endemic. It has been proved that $80 \%$ immunogenicity can be achieved after the second vaccination and the generated immunity can last for 1 year. If the third vaccination is completed, immunogenicity can reach $100 \%$ and the

Table 4 Some important problems of presently used Japanese encephalitis vaccine

\begin{tabular}{lll}
\hline Problems & Causes & Possible correction \\
\hline $\begin{array}{l}\text { I. Induction of unwanted adverse } \\
\text { neurological reactions }\end{array}$ & the nature of mouse brain-derived vaccine & $\begin{array}{l}\text { cell culture-based or recombinant } \\
\text { vaccine by advanced biotechnology }\end{array}$ \\
$\begin{array}{l}\text { 2. Loss of follow-up for the third } \\
\text { vaccination }\end{array}$ & $\begin{array}{l}\text { long interval in the present vaccination } \\
\text { schedule }\end{array}$ & new single-dose vaccination \\
3. Expensive & few manufacturers, nature of the disease, & promotion of equity in drug and \\
& which is common in poor countries & vaccine trade \\
\hline
\end{tabular}


generated immunity can last for at least 5 years ${ }^{42-48}$ However, the risk of excessive repeated booster vaccinations has been noted in the medical literature.

\section{Problems with the current vaccine}

The presently used vaccine is derived from mouse brain and can induce unwanted adverse neurological effects. This is the main reason for the need to find a new vaccine. A vaccine based on cell culture or recombinant technology has the potentioal to reduce unwanted adverse neurological effects. $^{49,50}$

\section{Problems with vaccination}

The presently used vaccination schedule, a three-dosage regimen over a year-long period, poses the problem of loss of follow-up, especially for the third dosage, resulting in an unsuccessful vaccination program. A single-dosage vaccine would overcome this disadvantage, and is the target of new vaccine development. Recently, a new Japanese encephalitis vaccine has been produced. The Japanese encephalitis vaccine IC-51, known as IXIARO, is the newest inactivated virus (strain SA(14)-14-2), which is manufactured in cultured Vero cells and needs only two doses in a vaccination program, ${ }^{51,52}$ thus solving the problem of a too-long vaccination program.

\section{Problems with vaccines}

In certain situations, some specific vaccines cannot be used, for example, in the pregnant. This presents a challenge for vaccinologists.

Affordability in developing countries can limit the effectiveness of vaccines. Although Japanese encephalitis vaccination is included in the national policy of some countries, high cost can still be a barrier. Japanese encephalitis is a disease of the poor and has received very little attention in wealthy countries except Japan.

\section{Finding a new vaccine for Japanese encephalitis}

Because of the problems discussed above, a new vaccine for Japanese encephalitis is needed. ${ }^{53-55} \mathrm{~A}$ new vaccine must be more effective, safer and of higher immunogenicity, and without the problems of the presently used vaccine, ie, adverse neurological effects and a long vaccination schedule.

Finding a new epitope is usually the first step in finding a new vaccine. The focus can be the immunogenic protein already used in vaccine production. Despite the protein's availability, it is still difficult to find a new epitope. It is a time-consuming process if based on classical techniques. Immunomics, ${ }^{56-59}$ a new branch of bioinformatics, can be useful for this purpose. Since Japanese encephalitis is a viral infection, the favorable epitope should be a specific $\mathrm{T}$ cell epitope which has an important role in immunogenicity via the $\mathrm{T}$ cell immune system. Alternative $\mathrm{T}$ cell epitopes can be useful in developing a multi-epitope vaccine.

Once the desired epitopes have been found, a new vaccine can be developed. Basically, because the vaccine is usually a peptide, advanced protein technology can be helpful in vaccine production. The new Japanese encephalitis vaccine should be a cell culture-based vaccine or a recombinant protein-based vaccine. The use of current genetic recombination technology can help produce the desired peptide in large amounts in a short time. This process also guarantees the purity of the new peptide, which would eliminate the problem of adverse neurological effects with classical Japanese encephalitis vaccine.

The next step in the process is testing the new vaccine's properties. Although they can be predicted from the vaccine's expression of visible action or function through in silico gene expression technology, classical in vitro and in vivo testing are still needed to confirm the vaccine's efficacy and safety. ${ }^{60-65}$ Several new new peptides have been discovered within the past few years, based on cell culture, recombinant technology or DNA technology, and their effectiveness is being trialed. ${ }^{60-65}$

The newest vaccine, IXIARO, was also developed by a cell culture technique. Its safety and efficacy have been confirmed, it is newly licensed in both Europe and the US, and is now poised to be licensed in many Asian countries..$^{51,52}$ Combined vaccines containing a specific vaccine for other viruses are also the focus of current developmental research on Japanese encephalitis vaccine. ${ }^{66,67}$ ChimeriVax-JE, a chimeric live attenuated vaccine using yellow fever (YF) 17D vaccine as a vector, is the best example. ${ }^{68,69}$ ChimeriVax-JE is accepted as a cost-effective prophylactic vaccine for Japanese encephalitis and can provide protective levels of neutralizing antibody after a single dose. ${ }^{70}$ ChimeriVax-JE can also protect against other viruses belonging to the Japanese encephalitis virus serocomplex. ${ }^{71}$ ChimeriVax-JE vaccine is licensed in some countries, for example, Thailand, China and India.

If the results from classical trials on a new vaccine are favorable, it will be launched on the market after passing the regulatory and registration processes of each country. Finally, post-marketing surveillance, similar to that for any new drug 
or vaccine, will still be required to complete the process of finding a new vaccine for Japanese encephalitis.

\section{Disclosure}

The author discloses no conflicts of interest.

\section{References}

1. Wiwanitkit V. Japanese encephalitis. J Ped infect Dis. 2007;4(2): 183-192.

2. Halstead SB, Jacobson J. Japanese encephalitis. Adv Virus Res. 2003;61:103-138.

3. Watanabe T. Japanese encephalitis. Nippon Rinsho. 2003; 61 Suppl 2:95-99.

4. Solomon T. Recent advances in Japanese encephalitis. $J$ Neurovirol. 2003;9(2):274-283.

5. Kawakatsu S. Encephalitis and psychosis. Ryoikibetsu Shokogun Shirizu. 2003;(40):303-306.

6. Solomon T. Exotic and emerging viral encephalitides. Curr Opin Neurol. 2003;16(3):411-418.

7. Kurane I. Japanese encephalitis virus. Nippon Rinsho. 2003; 61 Suppl 3:491-493.

8. Tolle MA. Mosquito-borne diseases. Curr Probl Pediatr Adolesc Health Care. 2009;39(4):97-140.

9. van den Hurk AF, Ritchie SA, Mackenzie JS. Ecology and geographical expansion of Japanese encephalitis virus. Аnпи Rev Entomol. 2009; 54:17-35.

10. Gould EA, Solomon T. Pathogenic flaviviruses. Lancet. 2008; 371(9611):500-509.

11. Weaver SC. Host range, amplification and arboviral disease emergence. Arch Virol Suppl. 2005;(19):33-44.

12. Konishi E. Clinical and epidemiological aspects of Japanese encephalitis. Nippon Rinsho. 2005;63(12):2138-2142.

13. Wada Y. Control of Japanese encephalitis vectors. Southeast Asian J Trop Med Public Health. 1989;20(4):623-626.

14. Philip Samuel P, Tyagi BK. Diagnostic methods for detection and isolation of dengue viruses from vector mosquitoes. Indian J Med Res. 2006;123(5):615-628.

15. Lounibos LP. Invasions by insect vectors of human disease. Annu Rev Entomol. 2002;47:233-266.

16. Saxena V, Dhole TN. Preventive strategies for frequent outbreaks of Japanese encephalitis in Northern India. J Biosci. 2008;33(4):505-514.

17. Barboza P, Tarantola A, Lassel L, Mollet T, Quatresous I, Paquet C. Emerging viral infections in South East Asia and the Pacific region. Med Mal Infect. 2008;38(10):513-523.

18. Bhargava A, Chatterjee B. Chikungunya fever, falciparum malaria, dengue fever, Japanese encephalitis... are we listening to the warning signs for public health in India? Indian $J$ Med Ethics. 2007;4(1):18-23.

19. Arai S, Matsunaga Y, Takasaki T, et al; Vaccine Preventable Diseases Surveillance Program of Japan. Japanese encephalitis: surveillance and elimination effort in Japan from 1982 to 2004. Jpn J Infect Dis. 2008;61(5):333-338.

20. Fontenille D. Transmission cycles of arboviruses in Madagascar. Arch Inst Pasteur Madagascar. 1989;55(1):7-317.

21. Mackenzie JS, Broom AK, Hall RA, et al. Arboviruses in the Australian region, 1990 to 1998. Commun Dis Intell. 1998;22(6): 93-100.

22. Dunstan RA, Seed CR, Keller AJ. Emerging viral threats to the Australian blood supply. Aust N Z J Public Health. 2008;32(4): 354-360.

23. Hore C. Important unusual infections in Australia: a critical care perspective. Crit Care Resusc. 2001;3(4):262-272.

24. McCormack JG, Allworth AM. Emerging viral infections in Australia. Med J Aust. 2002;177(1):45-49.
25. Hinson VK, Tyor WR. Update on viral encephalitis. Curr Opin Neurol. 2001;14(3):369-374.

26. Whitley RJ, Gnann JW. Viral encephalitis: familiar infections and emerging pathogens. Lancet. 2002;359(9305):507-513.

27. van-den-Hurk AF, Ritchie SA, Johansen CA, Mackenzie JS, Smith GA. Domestic pigs and Japanese encephalitis virus infection, Australia. Emerg Infect Dis. 2008;14(11):1736-1738.

28. Van Den Hurk AF, Johansen CA, Zborowski P, et al. Mosquito hostfeeding patterns and implications for Japanese encephalitis virus transmission in northern Australia and Papua New Guinea. Med Vet Entomol. 2003;17(4):403-411.

29. van den Hurk AF, Nisbet DJ, Johansen CA, Foley PN, Ritchie SA, Mackenzie JS.

30. Japanese encephalitis on Badu Island, Australia: the first isolation of Japanese encephalitis virus from Culex gelidus in the Australasian region and the role of mosquito host-feeding patterns in virus transmission cycles. Trans R Soc Trop Med Hyg. 2001;95(6):595-600.

31. Mwandawiro C, Boots M, Tuno N, Suwonkerd W, Tsuda Y, Takagi M. Heterogeneity in the host preference of Japanese encephalitis vectors in Chiang Mai, Northern Thailand. Trans R Soc Trop Med Hyg. 2000;94(3):238-242.

32. Misra UK, Kalita J. Seizures in Japanese encephalitis. J Neurol Sci. 2001;190(1-2):57-60.

33. Lam K, Tsang OT, Yung RW, Lau KK. Japanese encephalitis in Hong Kong. Hong Kong Med J. 2005;11(3):182-188.

34. Misra UK, Kalita J, Srivastava M. Prognosis of Japanese encephalitis: a multivariate analysis. J Neurol Sci. 1998;161(2):143-147.

35. Ishii T, Matsushita M, Hamada S. Characteristic residual neuropathological features of Japanese B encephalitis. Acta Neuropathol. 1977;38(3):181-186.

36. Schiøler KL, Samuel M, Wai KL. Vaccines for preventing Japanese encephalitis. Cochrane Database Syst Rev. 2007;(3):CD004263.

37. Tauber E, Dewasthaly S. Japanese encephalitis vaccines - needs, flaws and achievements. Biol Chem. 2008;389(5):547-550.

38. Wiwanitkit V. Vaccination for tropical mosquito borne encephalitis. Acta Neurol Taiwan. 2009;18(1):60-63.

39. Wills MR, Sil BK, Cao JX, Yu YX, Barrett AD. Antigenic characterization of the live attenuated Japanese encephalitis vaccine virus SA14-14-2: a comparison with isolates of the virus covering a wide geographic area. Vaccine. 1992;10(12):861-872.

40. Yamashita T, Ishikawa N, Hojo F, Shimada F, Ono K. Japanese encephalitis purified vaccine. II. Purity of the mouse brain vaccine purified by ultracentrifugation. Biken J. 1970;13(1):25-38.

41. Gupta RK, Misra CN, Gupta VK, Saxena SN. An efficient method for production of purified inactivated Japanese encephalitis vaccine from mouse brains. Vaccine. 1991;9(12):865-867.

42. Aizawa C, Hasegawa S, Chih-Yuan C, Yoshioka I. Large-scale purification of Japanese encephalitis virus from infected mouse brain for preparation of vaccine. Appl Environ Microbiol. 1980;39(1):54-57.

43. Yang SE, Pan MJ, Tseng HF, Liau MY. The efficacy of mouse-brain inactivated Nakayama strain Japanese encephalitis vaccine - results from 30 years experience in Taiwan. Vaccine. 2006;24(14):2669-2673.

44. Hanna JN, Smith GA, McCulloch BG, Taylor CT, Pyke AT, Brookes DL. An assessment of the interval between booster doses of Japanese encephalitis vaccine in the Torres Strait. Aust N Z J Public Health. 2005;29(1):44-47.

45. Itoh H, Kobyashif F, Toda M, Takashita I, Kitagawa S. Studies on mouse brain and chick embryo tissue in connection with the preparation of Japanese encephalitis vaccine. Kitasato Arch Exp Med. 1953;26(4): $243-258$.

46. Gowal D, Tahlan AK. Evaluation of effectiveness of mouse brain inactivated Japanese encephalitis vaccine produced in India. Indian J Med Res. 1995;102:267-271.

47. Hoke CH, Nisalak A, Sangawhipa N, et al. Protection against Japanese encephalitis by inactivated vaccines. NEngl J Med. 1988;319(10): 608-614. 
48. El'bert LB, Semenov BF, Karaseva PS, Pervikov IuV, Krutianskaia GL. Inactivated vaccine against Japanese encephalitis. The characteristics of a purified preparation from mouse brain. Vopr Virusol. 1983; (2):196-200.

49. Fujisaki Y, Miura Y, Sugimori T, Murakami Y, Miura K. Experimental studies on vertical infection of mice with Japanese encephalitis virus. IV. Effect of virus strain on placental and fetal infection. Natl Inst Anim Health $Q$ (Tokyo). 1983;23(1):21-26.

50. Plesner AM. Allergic reactions to Japanese encephalitis vaccine. Immunol Allergy Clin North Am. 2003;23(4):665-697.

51. Duggan ST, Plosker GL. Japanese encephalitis vaccine (inactivated, adsorbed) [IXIARO]. Drugs. 2009;69(1):115-122.

52. Kollaritsch H, Paulke-Korinek M, Dubischar-Kastner K. IC51 Japanese encephalitis vaccine. Expert Opin Biol Ther. 2009 Jul;9(7):921-931.

53. Zanin MP, Webster DE, Martin JL, Wesselingh SL. Japanese encephalitis vaccines: moving away from the mouse brain. Expert Rev Vaccines. 2003;2(3):407-412.

54. Bharati K, Vrati S. Japanese encephalitis: development of new candidate vaccines. Expert Rev Anti Infect Ther. 2006;4(2):313-324.

55. Kaur R, Vrati S. Development of a recombinant vaccine against Japanese encephalitis. J Neurovirol. 2003;9(4):421-431.

56. Davies MN, Flower DR. Harnessing bioinformatics to discover new vaccines. Drug Discov Today. 2007;12(9-10):389-395.

57. De Groot AS. Immunomics: discovering new targets for vaccines and therapeutics. Drug Discov Today. 2006;11(5-6):203-209.

58. Brusic V, Petrovsky N. Immunoinformatics - the new kid in town. Novartis Found Symp. 2003;254:3-13.

59. Maecker B, von Bergwelt-Baildon, Anderson KS, Vonderheide $\mathrm{RH}$, Schultze JL. Linking genomics to immunotherapy by reverse immunology - 'immunomics' in the new millennium. Curr Mol Med. 2001;1(5):609-619.

60. Li P, Zheng QS, Wang Q, et al. Immune responses of recombinant adenoviruses expressing immunodominant epitopes against Japanese encephalitis virus. Vaccine. 2008;26(46):5802-5807.

61. Lin CW, Liu KT, Huang HD, Chen WJ. Protective immunity of E. coli-synthesized NS1 protein of Japanese encephalitis virus. Biotechnol Lett. 2008;30(2):205-214.
62. Alka, Bharati K, Malik YP, Vrati S. Immunogenicity and protective efficacy of the E. coli-expressed domain III of Japanese encephalitis virus envelope protein in mice. Med Microbiol Immunol. 2007; 196(4):227-231.

63. Zhang F, Ma W, Zhang L, Aasa-Chapman M, Zhang H. Expression of particulate-form of Japanese encephalitis virus envelope protein in a stably transfected Drosophila cell line. Virol J. 2007;4:17.

64. Ge FF, Qiu YF, Yang YW, Chen PY. An hsp70 fusion protein vaccine potentiates the immune response against Japanese encephalitis virus. Arch Virol. 2007;152(1):125-135.

65. Feng GH, Liu N, Zhou Y, Zhai YZ, Li XM, Dou XG. Immunologic analysis induced by DNA vaccine encoding E protein of Beijing-1 strain derived from Japanese encephalitis virus. Intervirology. 2007;50(2): 93-98.

66. Beasley DW, Li L, Suderman MT, et al. Protection against Japanese encephalitis virus strains representing four genotypes by passive transfer of sera raised against ChimeriVax-JE experimental vaccine. Vaccine. 2004; 22(27-28):3722-3726.

67. Lai CJ, Monath TP. Chimeric flaviviruses: novel vaccines against dengue fever, tick-borne encephalitis, and Japanese encephalitis. Adv Virus Res. 2003;61:469-509.

68. Jones T. ChimeriVax-JE. Acambis. Curr Opin Investig Drugs. 2003;4:1019-1022.

69. Jones T. A chimeric live attenuated vaccine against Japanese encephalitis. Expert Rev Vaccines. 2004;3(3):243-248.

70. Monath TP, Guirakhoo F, Nichols R, et al. Chimeric live, attenuated vaccine against Japanese encephalitis (ChimeriVax-JE): phase 2 clinical trials for safety and immunogenicity, effect of vaccine dose and schedule, and memory response to challenge with inactivated Japanese encephalitis antigen. J Infect Dis. 2003;188(8):1213-1230.

71. Lobigs M, Larena M, Alsharifi M, Lee E, Pavy M. Live chimeric and inactivated Japanese encephalitis virus vaccines differ in their crossprotective values against Murray Valley encephalitis virus. J Virol. 2009;83(6):2436-2445.
International Journal of General Medicine

\section{Publish your work in this journal}

The International Journal of General Medicine is an international, peer-reviewed open-access journal that focuses on general and internal medicine, pathogenesis, epidemiology, diagnosis, monitoring and treatment protocols. The journal is characterized by the rapid reporting of reviews, original research and clinical studies across all disease areas.

\section{Dovepress}

A key focus is the elucidation of disease processes and management protocols resulting in improved outcomes for the patient.The manuscript management system is completely online and includes a very quick and fair peer-review system. Visit http://www.dovepress.com/ testimonials.php to read real quotes from published authors. 